\title{
FOREIGN MUSICIANS AT THE TRANSYLVANIAN COURT OF SIGISMUND BÁTHORY
}

\author{
PETER KIRÁLY \\ Kaiserslautern
}

Izvleček: Transilvanski princ Sigismund Báthory (1572-1613), ki mu je bilo med 1590 in 1599 posvečenih pet beneških glasbenih tiskov, je imel $v$ svoji službi številne tuje glasbenike. Veliko je bilo Italijanov, a tudi nekaj Nemcev in Poljakov. Trenutno je znanih ducat imen italijanskih glasbenikov, med katerimi je tudi skladatelj in urednik Giovanni Battista Mosto iz italijanskega Vidma ter organist in skladatelj Antonio Romanini iz Benetk. Zaposlitve njegovih tujih glasbenikov kažejo značilnosti, ki so vidne v poznejšem glasbenem življenju na transilvanskih dvorih v 17. stoletju in na nekaterih dvorih madžarskih aristokratskih družin.

Ključne besede: Sigismund Báthory, Transilvanija, Marija Christierna von Habsburg, posvetila, italijanski glasbeniki, Giovanni Battista Mosto, Antonio Romanini.
Abstract: Sigismund Báthory (1572-1613), Prince of Transylvania, to whom five Venetian music editions were dedicated between 1590 and 1599, had several foreign musicians in his service: mainly Italians, but also some Germans and Poles. The names of more than a dozen Italians are currently known, among them those of the composer and publisher Giovanni Battista Mosto of Udine, and the Venetian organist and composer Antonio Romanini. The employment of foreign musicians shares several features of the musical life of seventeenth-century Transylvanian courts, and that of Hungarian aristocratic families.

Keywords: Sigismund Báthory, Transylvania, Maria Christierna von Habsburg, dedications, Italian musicians, Giovanni Battista Mosto, Antonio Romanini.

Historical data from the sixteenth and the seventeenth centuries show that from the time of John Sigismund Zapolya (1559-1571) until the mid-1640s ${ }^{1}$ musicians from abroad were employed more or less continuously by the Princes of Transylvania. This is especially true for Sigismund Báthory (1572-1613), who reigned with interruptions from 1581 until 1601 (1581-1588 as a minor, 1588-1597/98, 1598-1599, 1601), and who had several foreign musicians, mainly Italians, in his service. ${ }^{2}$

${ }^{1}$ From the period before the rule of John Sigismund Zapolya no similar sources that might provide a clear picture of the court musicians survive. The very Italianate music of Valentin Bakfark, however, suggests that this musician had an Italian master who taught at the royal court, which moved to Transylvania after the fall of Buda in 1541. See Király, "Valentin Bakfark", 201-210. Király, "An Internationally Renowned Virtuoso", 65-66.

2 On Báthory, there is a short chapter with an extensive bibliography: Bárdos, "Fejedelmi és foúri zeneélet", 106-109. 
Along with some neighbouring counties, Transylvania, at that time in south-east Hungary, became separated from Hungary as a result of the Ottoman invasion leading to the fall of Buda in 1541. During the 1550s a principality was founded there that depended greatly on the Ottoman Sublime Porte. The Transylvanian Princes, like most of the inhabitants, were Calvinist Protestants. Exceptionally, the rulers belonging to the House of Báthory were Catholics. When Sigismund Báthory, then aged sixteen, was enthroned in 1588, hopes of a "recatholization" arose. The young prince, an orphan, had been educated by the Jesuits. Although he never visited Italy, he spoke Italian well. He received a great deal of support from Italy, as well as from the Habsburgs - Báthory was the only Transylvanian Prince ever to marry a Habsburg Princess. His supporters were aiming at the recatholization of Transylvania, a goal never realized.

Contemporary and later sources - mostly written by Protestants - repeatedly complain about the influence of the Jesuits and the Italians, who, as it was claimed, "corrupted his soul" with Italian idleness. ${ }^{3}$ Báthory was indeed obviously fond of music. One of the works dedicated to him, Il Transilvano (1593) by the Venetian Franciscan monk Girolamo Diruta, characterizes Báthory as a "cordialissimo amatore di musica e di concerti". ${ }^{4}$ Although Diruta must have received this information at second hand, since he never visited Transylvania, others sources confirm it. The diplomatic emissary Franco Sivori of Genoa stated in a report written in 1590 that earlier, while visiting Gyulafehérvár (Alba Iulia in Romania) in 1584, he had come across musicians, to which he appended the comment "de quali musici il Principe sempre tiene una quantita con honorato trattamento". ${ }^{5}$ One of Báthory's Italian musicians, Pietro Busto, characterized the Prince in 1595 as "bonissimo musico in ogni sorte d' istromento[,] et compone opere di musica al pari de piu eccelenti Autori", and for his pleasure the Prince had "una compagnia de buoni musici". 6 The German traveller Veit Marchthaler of Ulm, who stayed in Hungary some time between 1588 and 1600, noted that the Prince "hat zimblich studiert, kan guet Walsch, Voluptas bringt auch schon Venerem, auf Tanczen, Springen, Fechten, Musica, Orgeln und dergleichen last er vil gehoren". After his first resignation of the Principality in 1597, while

${ }^{3}$ Consider, for example, the opinion expressed by Prince János Kemény (reigned 1661-1662), who was present at the court from the early 1620s: "although Sigismund was taught with good intentions, but according to the behaviour of Italians and other foreign nations [...]. His mind was taken up by music and other idleness; he squandered much on account of such idleness" ("Zsigmondot, elhiszem jó végre ugyan, mindazáltal olaszos és egyéb idegen nemzetek conversatiójában nevelvén [...]. Muzsika s egyéb hijába valóság fogta el elméjét, mely haszontalanságokra sokat is tékozlot"). Windisch, Kemény János, 21. See also Marchthaler's report referred to in note 7, below.

4 Haraszti, “Sigismond Báthory”, 195; Haraszti, “'Il Transilvano' di Girolamo Diruta”, 117.

5 Balogh, Kolozsvári köfaragó mühelyek, 285: "in un cantone molti musichi con li istrumenti alla italiana, con un organo suavissimo, de quali musici il Principe sempre tiene una quantita con honorato trattamento [...]. Et al suono de varij Instrumenti, hebbi un regio bachetto alla Ittaliana". The original manuscript is in Rome, Biblioteca Apostolica Vaticana, Fondo Ferraiuoli, no. 43: "Memoriale delle cose occorse a me Franco Sivori del Signor Benedetto doppo della mia partenze di Genoua l'anno 1581 per andar in Vallachia. 1590."

${ }^{6}$ Bascapè, Le Relazioni, 171; Constantinescu, "Muzica în Transilvania", $175 \mathrm{n} 184$.

7 Németh S., "Erdélyi fejedelmi udvar Marchthaler útleírásában”, 335. I have viewed the German 
on his way to Oppeln (Opole in Poland), Báthory reached Breslau (Wrocław) on 13 July 1598, where he "auch die Orgel [...] wol besichtiget". ${ }^{8}$ Typically for the Prince, when his bride from Graz, Maria Christierna Leonora of Habsburg, arrived in Transylvanian territory with her retinue in the summer of 1595, Báthory, according to a contemporary, went along incognito "con pochi suoi fedeli servitori Ongari et alcuni Italiani" to see her, hiding among his musicians. ${ }^{9}$

Table 1

Five Italian musical editions printed in Venice were dedicated to Báthory

\begin{tabular}{|l|l|l|l|}
\hline Giovanni Battista Mosto & Motecta quinque vocum & 1590 & RISM M 3815 \\
\hline Girolamo Diruta & Il Transilvano (The title “Il Transilvano" refers to Báthory) & 1593 & $\begin{array}{l}\text { RISM D 3134 } \\
\text { RISM } 15939\end{array}$ \\
\hline Giovanni Battista Mosto & Il primo libro de madrigali & 1595 & RISM M 3816 \\
\hline Philippe de Monte & Il decimosettimo libro de madrigali & 1595 & RISM M 3388 \\
\hline Giovanni Bassano & Concerti ecclesiastici & 1599 & RISM B 1234 \\
\hline
\end{tabular}

Music histories frequently cite these dedications as proof of Báthory's fondness for music (see table 1). But one should not forget that, leaving aside Mosto's publications, the dedications did not reflect personal contacts at all. They were commissioned by intermediaries. Such dedications were, in fact, frequently employed as political instruments. ${ }^{10}$ This was probably also true in Báthory's case.

In the light of what has been said, one might easily assume that it was Báthory's education, his close contacts with Italians and the Habsburgs and especially his personal taste, that shaped the character of his court and lay behind his distinctive music ensembles, which have been supposed by later observers and modern scholars to be unique among the courts of the Transylvanian Princes. A few decades later, however, Gabriel Bethlen, a Protestant Prince who had received a different education and was politically opposed to the Habsburgs, maintained a similar court between 1613 and 1629. Bethlen likewise employed a substantial number of foreign musicians - although probably fewer from Italy. ${ }^{11}$ It appears that the courtly life and the court music of Báthory and Bethlen were influenced, rather, by the fact that they wished to conform to international standards, aspiring towards a court displaying the magnificence that an important ruler should cultivate according to contemporary opinion.

Concerning Báthory's court musicians, we possess a lot of scattered information that more often than not comes from untrustworthy secondary sources. The most important documents of the court administration (e.g., contracts with musicians, lists of court musicians, payment records) are unfortunately lost as a result of the occupation, pillage and disastrous burning of Gyulafehérvár by Ottomans and Tartars in 1658. Researchers have to depend on little titbits of information gleaned from other sources. Although there is

original by courtesy of Ms. Katalin Németh S.

${ }^{8}$ Büsching, Jahrbücher der Stadt Breslau, 188.

9 Haraszti, "Sigismond Báthory", 206.

${ }^{10}$ Lindell, "Das Musikleben am Hof Rudolfs II.", 81.

${ }^{11}$ See, for instance, Király, "Foreign musicians", 256-257. 
a considerable quantity of data confirming that many different foreign musicians were employed, information that contains more than hints about their origins, instruments or musical function is scarce. Full names are rarely given, and it is rare that anything is known about the former or later life and activity of any musician.

Of course, in addition to the foreigners, there were more than a few local musicians employed by Báthory. But even here it is not always easy to achieve certainty. Several cases underline the fact that foreign musicians were also referred to in Hungarian documents in the customary way among Hungarians; with a first name in the specific form used among Hungarians, attached to the name of the instrument they played (or musical function they held). To give just one example: Antonio Romanini - to whom we will return later - is named in Hungarian in one of the city records of Kolozsvár (Clausenburg, Cluj in Romania) "Antal urunk orgonása" ("Antal the organ player of our Lord"). In other cases, where we lack the additional information present in Romanini's case, it remains unclear whether any foreigners - and if so, how many - lie concealed behind similar Hungarian name-forms.

Notwithstanding the above reservations, the names of more than a dozen Italians have so far been unearthed for the years of Báthory's reign. But in all likelihood there were more. In a papal brief of Clement VIII written on 10 March 1592 for the legate Attilio Amalteo we find the statement: "Sono in Transilvania in servitio del prencipe una buona quantitá di musici italiani”. ${ }^{12}$ Much later, in the city records of Kolozsvár (20 May 1596), we find mention of two carriages packed with Italian musicians. ${ }^{13}$

Báthory's Italians originated (or possibly arrived in Transylvania) from cities such as Ancona, Bologna, Brescia, Genoa, Roma and Udine, and - unsurprisingly - in their majority from Venice. At least in a few cases, we know something about their former activities in cities such as Padua and Venice, or as court musicians in Florence, Mantua, Graz and Innsbruck. Documents show that some of the Italians brought their families with them; and there were others, such as Mosto and Zephyro Spira from Venice, who married in Transylvania. Additionally, some foreigners died and were interred in Gyulafehérvár or elsewhere in Transylvania, such as Mosto, Spira and a certain "Mattheus germanus musicus" (1593)..$^{14}$

It was supposed by earlier scholars - based on a misinterpretation of a remark by the Transylvanian archivist, historian and chronicler István Szamosközy, a contemporary of Báthory - that these Italian musicians first arrived in Transylvania around $1592,{ }^{15}$ but sources indicate that they had probably commenced activity already during the 1580 s.

${ }^{12}$ Veress, Erdélyországi pápai követek jelentései, 5.

${ }^{13}$ Arhivele Statului Cluj, fond Primăria Cluj, city records (hereafter referred to as "Kolozsvár city records"), 1596, 6/XXIX, 32: "ket zekerre valo olaz musikusokat viznek Desre, portekaikal egietembe".

14 "HIC IACET MAT / THEVS GERMANVS MVSICVS QUO / NDAM ILLVSTRI / SSIMI PRINCIPIS TRANSSYLVANIAE QVI / [I!] ANNO NDXCIII [!] DIE 10 F / EB[ruarii] ANIMA / M DEO RED/DIDIT / 159[?]" - courtesy of András Kovács (Cluj).

${ }^{15}$ See Szilágyi, Szamosközy István történelmi maradványai, 25; Abbaffy and Kozocsa, Szamosközy István, 179. See also Bethlen, Historia, 3:15. This erroneous, but even today widely accepted, view has been questioned by Albert Gárdony on the basis of the strong general Italian influence on the Báthory court long before 1592. Gárdonyi, "A Báthoryak", 34. 
The Genoese traveller Sivori remarked in a report that in 1584 in Gyulafehérvár he had seen "molti musichi con li istrumenti alla italiana". ${ }^{16}$ Sivori, admittedly, did not state that the musicians were Italians; similarly, Pietro Busto, who in 1595 wrote only that in replacement of the Jesuits, who in 1588 had been forced by the Transylvanian assembly to leave the country, the Prince had "una compagnia de buoni musici". ${ }^{17}$ Then the Jesuit Campano stated on 17 May 1590 only that the Prince "Optimam capellam excellentibus musicis refertam sustentare". ${ }^{18}$

Other sources, fortunately, are clearer: On 5 October 1590 the city of Beszterce (Nössen, Bistritz, Bistriţa in Romania) transported an Italian lute-player in the Prince's service, ${ }^{19}$ and Giovanni Battista Mosto was already styling himself on the title page of his Motecta quinque vocum (the foreword to which is dated 1 October 1590) "apud Serenissimum principem Transilvanie [...] musices moderator". ${ }^{20}$ Pope Clement's already mentioned brief of 1592 similarly confirms the employment of "una buona quantità di musici italiani".

The contemporary historian and chronicler István Szamosközy - an important and trustworthy witness - listed some of Báthory's musicians whom he remembered. In this account there appears a certain "Franciscus magister capellae, musicus, Anconitanus, Italus". ${ }^{21}$ If this person was identical with the musician identified only by the forename "Francisco" who on 24 April 1590 was transported together with Báthory's other musicians by the city of Kolozsvár, ${ }^{22}$ it would appear that Francesco of Ancona preceded as magister capellae Mosto, who - as we have just seen - was already calling himself on 1 October 1590 "apud Serenissimum principem Transilvanie [...] musices moderator".

At the moment nothing else is known about Francisco of Ancona. This is not the case with the northern Italian Giovanni Battista Mosto from Udine, a renowned composer whose life and work are quite well documented. Mosto served in Transylvania in a formal role from around 1590 until 1595-1596, but after 1593 with interruptions: so to speak,

${ }^{16}$ See note 5 , above.

${ }^{17}$ Gárdonyi, "A Báthoryak", 35: "in luogho di quelli volse per suo diporto una compagnia de buoni musici”.

${ }^{18}$ Lukács, Monumenta Antiquae Hungariae, 535. I have this information courtesy of Péter Erdősi.

${ }^{19}$ Arhivele Statului Cluj, fond 44 Bistriţa, city records (hereafter referred to as Beszterce city records) IVa 25, 20: "Vectura in dypsa testudinarii Ill[ustrissi]mi principis"; also Arhivele Statului Cluj, fond 44 Bistriţa, Missiles nr. 1590/36, 3.: "Jtem f[ürstlichen] gnaden Welschen Lattynisten ghen Neumarck gefuret vnndt ihn frayen kosten gehalten fl. 8.".

${ }^{20}$ RISM M 3815, only known example: Kassel, Landesbibliothek, $4^{\circ}$ Mus. 6 [Internet: http:// orka.bibliothek.uni-kassel.de/viewer/image/1407319467807/117/ (16 September 2015)]; For the description of the colligatum to which the Mosto edition belongs, see: Horstmann, Katalog der Musikdrucke, 65-69.; Király, "Giovanni Battista Mosto figyelembe nem vett kiadványa”, 384-387.

${ }^{21}$ Szilágyi, Szamosközy történelmi maradványai, 76-77; Abbaffy and Kozocsa, Szamosközy István, 32; Haraszti, "Sigismond Báthory", 202, with a French translation of Szamosközy's remarks. For a German translation of Szamosközy's listing, see: Főkövi, "Die Zigeunermusik in Ungarn”, $147-148$.

${ }^{22}$ Kolozsvár city records, 1590, 4/XXI, 81: "Vitte konikol [Konkoly] Demeter Hynnyadra 4 Loval vayda Musikassit, franciscot es teob egyetembe". 
"always on the run". ${ }^{23}$ After the Prince - because of a rumoured Turkish attack - dispatched his musicians to Cracow in September 1593 Mosto returned only around the turn of 1594-1595, and obviously only briefly. In March 1595, already in Venice, he published his Il primo libro de madrigali. It is in this second work dedicated to Báthory that Mosto claimed to have composed his madrigals mainly in Transylvania: "Sono la maggior parte di questi miei Madrigali o composti per commandamento di V.A.S. o nelli amenissimi, e fertilissimi Paesi del suo sempre felice stato di Transilvania." He probably presented the new edition to the Prince, who at some point prior to May 1595 made over to Mosto a house in Gyulafehárvár in the "olasz utca" (Italian street), ${ }^{24}$ and made him, according to Mosto's foreword to the Madrigali, a "Gentil'huomo della sua camera". It is likely that the musician participated, in the summer of 1595, as magister capellae for the wedding festivities of Sigismund Báthory and Maria Christierna of Habsburg. But soon afterwards Mosto returned to Italy, where - possibly without Báthory's permission - he resumed his former post at the Duomo of Padua. Revisiting Gyulafehérvár in order to bring his family to Italy, he died in the spring or summer of 1596 . He was buried in the Cathedral of Gyulafehérvár. ${ }^{25}$

Another noteworthy musician, Don Matteo Foresto, belonged at least during the period 1587-1591, to a musical ensemble in Mantua directed by Giaches de Wert. ${ }^{26}$ Foresto was sent, armed with letters from the Duke of Mantova, Vincenzo Gonzaga, to Poland and Transylvania. He clearly joined Báthory's musicians there - possibly shortly before September 1593, when the Italians hurriedly escaped to Cracow because of an expected Ottoman attack. Foresto is most probably identical with a "Matthaeus Mantuanus musicus" listed by Szamosközy. In the summer of 1594 Mosto and Foresto turned up in Regensburg, when they joined the Hofstaat of the Archbishop of Köln, Ernst von Wittelsbach. ${ }^{27}$ Unlike in Mosto's case, we have no evidence that Foresto ever returned to Transylvania.

${ }^{23}$ On Mosto, see Király, “Giovanni Battista Mosto”, 540-541; Király, “Giovanbattista Mosto 'száguldó muzsikus"”, 53-68.

${ }^{24}$ Arhivele Statului Cluj, Acte fascicolate IV, 104; Veress, Documente, 216; Balogh, Kolozsvári köfaragó mühelyek, 294: On 8 May 1595 Báthory donated a house to his musician Pietro Busto, and according to the description of its location, it was situated in the "Italian street" ("Olasz utca") close to Mosto's house: "in platea Olasz ucza vocata, intra muros civitatis huius Alben[sis], in vicinitatib[us] domorum ab unius Generosi Ioannis Baptistae Musto Magistri Chori Musicorum n[ost]rorum".

${ }^{25}$ The tombstone was transcribed by Johannes Georgius Vett in 1697 as follows: "Nobili Johanni Baptistae mastro [Mosto] Veneto | Serenissimi Transylvaniae Principis Sigismundi Chori Praefecto: | Altima marito et Petrus Angelus Musitanus socero dilectissimo | Et desideratissimo moerentes re[...]erunt | Vixit annos, menses huius Saeculi MDXCVI." See: Balogh, Kolozsvári köfaragó mühelyek, 305-306; Mosto's father-in-law, "Petrus Angelus Musitanus", mentioned on the tombstone, might be the same person as the equerry "Petrus Angelus Senex", as mentioned by Szamosközy. Szamosközy mistakenly gives 1597 as the date of Mosto's death. See Abbaffy and Kozocsa, Szamosközy István, 32.

${ }^{26}$ Mantova, Archivio di Stato, Archivio Gonzaga, busta 395, fol. 156v; also busta 410B, Reg. 43, fol 43/[18]; Canal, Della musica in Mantova, 87, mentions Foresto as a musician in 1587.

${ }^{27}$ Mantova, Archivio di Stato, Archivio Gonzaga, busta 525. (29. 07. 1594, Foresto's letter to the Duke of Mantua). Haraszti, "Sigismond Báthory”, 204; Szilágyi, Szamosközy történelmi 
Simone Ponte - according to Szamosközy, "Simon Ponte Florentinus, musicus" served between 1567 and 1569 as a musician at another important Italian court: that of Cosimo de' Medici. ${ }^{28}$

Not much is known about Pietro Busto, to whom we owe a report on Báthory's court: a possibly fictional letter by Busto to his brother dated 21 January $1595 .{ }^{29}$ Szamosközy identifies him as "Petrus Busti, musicus, Brixianus", thus from Brescia, also remarking that a painter called Nicolaus married his daughter. ${ }^{30}$ Prince Báthory granted Busto ("Nobilis Petri Busti Itali, musici nostri”) a house in Gyulafehérvár in the neighbourhood of Mosto's house on 8 May 1595; the deed recording this mentions that Busto has been serving the Prince for years and is about to continue to do so. ${ }^{31}$ However, it is not known how long Busto in the event remained in Transylvania. His earlier and later life is still undocumented. ${ }^{32}$

There is a little information about three of Báthory's Italian keyboard players. Szamosközy mentions two of them. About a certain "Gothardus Romanus organista" 33 whom he lists, further information is still missing. The same is true of the "virginalist of His Highness", in Hungarian fashion called in the city records Olasz Gáspár (Gasparo the Italian), who was given transport on 6 July 1595 by Kolozsvár. ${ }^{34}$ However, on 23 September of the same year a certain Italian, named in the records in Hungarian as "Bellyci Gaspar Olasz", was transported, together with several other Italians. ${ }^{35}$ If he was the same keyboard

maradványai, 76-77; Abbaffy and Kozocsa, Szamosközy István, 32; Fleischman von Puntzelwitz, Kurtze vnd aigentliche Beschreibung, [unpaginated]; Mosto is listed among the "Cammerdiener", and "Matheo Foresto" among the musicians; Mantua, Archivio di Stato, Archivio Gonzaga, busta 468, fasc. II 2, fols 196-199 (on 26 May 1594 Enea Gonzaga reports a meeting between the Duke of Mantua and Foresto in Regensburg). Also busta 525 (Foresto's letter to the Duke).

${ }^{28}$ Szilágyi, Szamosközy történelmi maradványai, 76-77; Abbaffy and Kozocsa, Szamosközy István, 32; Ponte is described in one payment record in Florence as "ciciliano anzi venetiano". See Kirkendale, Court Musicians in Florence, 103 (no. 24). I have this information courtesy of Péter Erdősi.

${ }^{29}$ Rome, Biblioteca Apostolica Vaticana, Urb.lat. 817. pt. 2, 337r-350v: Busto, Pietro: "Descrizione della Transilvania fatta da me ms. Pietro Busto bresciano musico di quel sereniss[i]mo Principe [Zsigmond Báthory] l'anno 1595 Sommario Con notizie sul principe stesso", dated: "Alba Giulia, 21 genn. 1595”. Other copies in: Paris Bibliothèque nationale, Milan Biblioteca Ambrosiana, Cambridge Trinity College.

${ }^{30}$ Szilágyi, Szamosközy történelmi maradványai, 76-77; Abbaffy and Kozocsa, Szamosközy István, 32: "ennek leanyat vötte az Pictor Nicolaus". His son-in-law might be identical with a Greek painter from Crete mentioned by Szamosközy, who, according to his account, was still living in Kolozsvár in 1607: "Nicolaus Grecus Cretensis, Pictor, ezt mostis él Colosuarat, 1607".

${ }^{31}$ Arhivele Statului Cluj, Acte fascicolate IV, 104; Veress, Documente, 216-217: "Nobilis Petri Busti Itali musici nostri, quae ipse serenit[at]i n[ost]rae, in hac arte sua iam ab aliquot annis fideliter exhibuit et impendit, ac in futurum quoque exhibiturus et impensurus est".

${ }^{32}$ Emil Haraszti reports that he tried without success to find traces of Busto in Brescia. Haraszti, "Sigismond Báthory", 197.

${ }^{33}$ Szilágyi, Szamosközy történelmi maradványai, 76-77; Abbaffy and Kozocsa, Szamosközy István, 32.

${ }^{34}$ Kolozsvár city records, 1595, 6/XVIIa, 79: “Olaz Gaspart Wrunk Öf[elsé]ge Virginassat vitte Zillahig Pap István".

${ }^{35}$ Kolozsvár city records, 1595, 6/XVIIa, 101: "Bellyci Gaspart Olaßt: Az olaz Loassok felet, és egy bör ßekeret, mely 8 olazzal rakwa wolt, Darabos Janostol Vitte Thordara 6 loal Kalmar Istwan”. 
musician, his name might be Bellis or something similar, which might serve as a starting point for future research.

Much more substantial information is available about an organist called by Szamosközy "Antonetto Venetus", who turns up in 1592 and 1597 in the transportation records of Kolozsvár. ${ }^{36}$ This musician mentioned by Szamosközy - as earlier scholars have found out - was Antonio Romanini from Venice, a pupil of Andrea Gabrieli, who in 1586 failed to obtain the post of second organist at San Marco, which had become vacant after Gabrieli's death. ${ }^{37}$ Romanini is mentioned by Diruta in Il Transilvano as Báthory's organist, who had informed this author about the noble soul and rare qualities of the Prince. ${ }^{38}$ Diruta published a "[Toccata] dell' octavo tono di Antonio Romanini", ${ }^{39}$ which is one of the two known pieces ascribable to Romanini, while Giovanni Bassano described Romanini in the dedication to Báthory of his own Concerti ecclesiastici (1599) as his friend and the Prince's organist. ${ }^{40}$

Szamosközy described "Antonetto Venetus" as a priest guilty of fornication and murder. While nothing is known about criminal activity of this kind, according to a Kolozsvár transportation record Romanini had a wife and child with him in February 1597, ${ }^{41}$ which - if he was indeed a priest - could at least partly support Szamosközy’s accusation. One might ask: could this be the reason why Romanini, unlike the other Italians, remained in Transylvania for a long time? He stayed there at the latest from the summer of 1592 until 1598/1599 at the earliest. At all events, Antonio Romanini clearly played an important role as an intermediary between Venetian musicians and Báthory’s court in Gyulafehárvár.

The Prince also employed lute players from Italy. We know of three such players at the moment. On 5 October 1590 an Italian lutenist of unknown name, already mentioned, was given transport by the city of Beszterce. ${ }^{42}$ On 27 April 1595 Kolozsvár transported the Venetian knight and diplomat Giovanni Michele (Giovanni Michele, Juan Michiel

${ }^{36}$ Kolozsvár city records, 1592, 5/XIV, 290, 297: 6 July 1592: “6 lovan vyzik postan az feyedelem orgonasat anttaltt Tordara", 25 October 1592: "Antalt vrunk Orgonasat: Postan vijzi Beil Mihaly: 4 Lova[n] Tordara"; Kolozsvár city records, 1597, 7/XIV, 72: 24 February 1597: "Wrwnk w felsege orgonassat Antoniust widte felesegestwl germekestwl Sal[v]us Conductus wala Nalla widtek [...] 6 lovon szekeren Tordaig".

${ }^{37}$ Caffi, Storia della musica sacra, 189: "Andrea Gabrieli, sornomato da Canareggio, sel disputarono tre di lui allievi: Vincenzo Bellaver (Bell'Haver) Paolo Giusto, dello da Castello, ed Antonio Romanini". The position of organist was given to Vincenzo Bellavere (Bell'Havere) on 30 December 1586.

38 “[...] per relatione dall' Eccellentiss. M. Antonio Romanini Suo Organista”; Barlay and Pernye, "Diruta: Il Transilvano", 50.

${ }^{39}$ On pages 43-46 of the 1597 edition of Diruta's Il Transilvano. See: http://purl.org/rism/BI/1597/25; Haraszti, “Sigismond Báthory”, 203n2. On Romanini’s Toccata, see Zászkaliczky, Pernye and Barlay, Il Transilvano.

${ }^{40}$ Gaspari, Catalogo, 378. Bassano is not mentioned in musicological studies concerning Báthory, the only exception being Barlay and Pernye, "Diruta: Il Transilvano", 50.

${ }^{41}$ Abbaffy and Kozocsa, Szamosközy István, 32: "Antonetto Venetus, organista, ez egÿ gilkos parazna lator pap vala." See also note 36, above (24 February 1597).

${ }^{42}$ See note 19 , above. 
etc.), as well as another Venetian nobleman plus a lutenist of the Prince, who all returned to their "patria" - thus obviously to Venice. ${ }^{43}$

As a result of the rumoured attack of the Ottoman Turks, two Italian musicians in the Prince's service, Pompeius and Julius, both from Bologna, reached Beszterce around the end of 1593 en route from Transylvania towards southern Poland. ${ }^{44}$ Báthory's salvus conductus, issued at Gyulafehárvár on 20 September, for "Nobilis Julius Crema Bononiens[sis]", still exists. ${ }^{45}$ This musician, Julio Camillo Crema or Crodi belonged between 1581 and some time before 1586 to the Hofkapelle of Archduke Ferdinand in Innsbruck as a tenor and lutenist. ${ }^{46}$ Unlike the others, Crema/Crodi returned after 1593 to Transylvania. Szamosközy refers to him as "Julius Crodi Bononiensis, Cubicularius Sigismundi, 1598". ${ }^{47}$ The musicians finally departed from Transylvania via Poland to Italy, obviously after Báthory's abdication in $1599 .{ }^{48}$

Crema or Crodi's companion during their flight of 1593 appears in Szamosközy's list as "Pompejus Bononiensis, musicus". ${ }^{49}$ Pompeius likewise returned to Báthory probably around the turn of 1594/1595, and he made his reappearance together with Mosto. ${ }^{50}$ How long Pompeius remained thereafter in Transylvania is not known, but it is likely that he was among the musicians performing at the Prince's wedding.

Besides the names already mentioned, the following Italian musicians are also listed by Szamosközy: a certain "Zephyrus Spira, Venetus", who married the daughter of one

${ }^{43}$ Kolozsvár city records, 1595, 6/XVIIa 56, 172: "Donatus Hector Nobilis Venetus, Cavallir Urammal jött vala be: És vele vala urunk 1 Lantossa: Redeunt in Patriam", "Donatus Hector nobilis Venetus és Wrunk ö felsége egyik Lontossat [sic !] [...] Desig vitte Böl András”. Already referred to (without citation of the text and giving an erroneous date of 17 April) in Balogh, Kolozsvári köfaragó mühelyek, 231.

${ }^{44}$ Beszterce city records, IV a 25 (1590-1623), 102, 117: "expense hospitalittis in Pompeium et Julium Italos Ill[ustrissi]mi principis Musicos fatte ex mandato Ill[ustrissi]mi principis [fl.] 18 [d] 57", "aurige qui eos in Rettek usque direxit [d.] 75", "Thome dobos cum illis misso in Lapos sumptus [d.] 60", also 3 December: "Sumptus Thome dobos in Huzt cum Italis Musicis Ill[ustrissi] mi principis ex mandato eiusd[em] Cels[itudinis] [fl.] 1 [d] 50".

${ }^{45}$ Arhivele Statului Cluj, fond 44 Bistriţa, IIIa. nr. 8. (Magistratsprotokoll), 143.

${ }^{46}$ Senn, Musik und Theater, 125.

${ }^{47}$ Abbaffy and Kozocsa, Szamosközy István, 32.

${ }^{48} \mathrm{Crodi}$, together with another Italian, was arrested en route in June by the Habsburg authorities in response to political accusations. They were soon released. Tiroler Landesarchiv, Innsbruck, Regierungskopialbuch, 82: "Von der Kaiserlichen Majestät", 1595-1599, fol. 490 (1 June 1599); fols 507v-509 (7 August 1599); fols 507r-v (15 August 1599); as well as Regierungskopialbuch, 84: “An die Kaiserl. Majestät”, 1598/1599, fol. 451 (11 June 1599); fols 493-495 (19 July 1599); fols 525-526 (26 July 1599); fols 522v-523 (9 August 1599); fols 523v-524v (30 August 1599). The case is briefly discussed in Waldner, "Verzeichnis", 173. See also Senn, Musik und Theater, 125.

${ }^{49}$ Szilágyi, Szamosközy történelmi maradványai, 76-77; Abbaffy and Kozocsa, Szamosközy István, 32.

${ }^{50}$ On 6 January 1595, writing from Gyulafehérvár, Arnulf Uchański informed Cinzio Aldobrandini in Rome about Mosto and Pompeius, two Italians who had arrived from Cracow ("veniunt duo itali Mustus et Pompeius Cracovia"), and reported on Cardinal Andreas Báthory's speech in the Polish Sejm against Sigismund Báthory. Rome, Archivio Doria-Pamphilij Fondo Aldobrandini, busta 5, fols 124r-126v. I have this information courtesy of Tamás Kruppa. 
of the City Councillors of Gyulafehérvár and died in that city. ${ }^{51}$ Szamosközy also records "Nicoletto Menti cantor, venetus", 52 who might possibly be the "Nicolaus Musicus" mentioned briefly by the historian Farkas Bethlen in his description of the turbulent year 1602. ${ }^{53}$ The last Italian in Szamosközy's list is “Johannes Maria Rodolphus Genuensis, musicus". ${ }^{44}$ Finally, a certain "Musicus Vinantius" is mentioned in the city records of Kolozsvár in 1594; this man was given transport in the company of an Italian priest serving the Prince. ${ }^{55}$ It is not clear, however, whether this musician was similarly an Italian.

Besides Italians, some other foreigners, mainly Germans, are known to have been members of Báthory's court. At all events, they do not seem to have been as numerous as the Italians, and we possess at present even fewer details about their lives and careers.

During the sixteenth and seventeenth centuries the musicians from German-speaking lands who were employed in Hungary were mainly players of wind instruments, especially trumpeters. This might well be the case with the Germans at Báthory's court. Szamosközy remarks of "Joannes Chalibus, Halberstadensis, Saxo musicus", that he married the former wife of a trumpeter, Trombitás Ferencz, ${ }^{56}$ which could be a marriage to the widow of a deceased colleague. Two musicians from Prussia, "Joannes Borussus, musicus" and "Constantinus musicus, Borossus", are also listed by Szamosközy. Further documentation on either is missing. Also, in the ambulatory to the Cathedral of Gyulafehérvár there is a tombstone for a certain "Mattheus germanus musicus" in Báthory's service, who died on 10 February $1593 .{ }^{57}$ During Báthory's third return to Transylvania, on 2 April 1601, according to the city records of Beszterce, the city paid a German trumpeter in Báthory's employ. ${ }^{58}$ Finally, on 10 April 1597 a German "Zenkenblaser" (cornettist), who might have belonged either to the court of Báthory or to that of his wife Maria Christierna, received a payment. ${ }^{59}$

In the light of the usually close connections to Poland, surprisingly only one musician

${ }^{51}$ Szilágyi, Szamosközy történelmi maradványai, 76-77; Abbaffy and Kozocsa, Szamosközy István, 32: "Zephyrus Spira, Venetus, musicus et hic Zephyrus mortuus Albae; ez vötte el volt az Nyirö István leányát"; Nyírő was a City Councillor of Gyulafehérvár during the 1590s. See Balogh, Kolozsvári köfaragó mühelyek, 297-298; also Kovács, Gyulafehérvár város jegyzökönyvei, 25 and 145.

${ }^{52}$ Szilágyi, Szamosközy történelmi maradványai, 76-77; Abbaffy and Kozocsa, Szamosközy István, 32.

${ }^{53}$ Bethlen, Historia, 5:165.

${ }^{54}$ Szilágyi, Szamosközy történelmi maradványai, 76-77; Abbaffy and Kozocsa, Szamosközy István, 32.

${ }^{55}$ Kolozsvár city records, 1594. 6/IV. 10. Balogh, Kolozsvári köfaragó mühelyek, 231.

${ }^{56}$ Szilágyi, Szamosközy történelmi maradványai, 76-77; Abbaffy and Kozocsa, Szamosközy István, 32-33: "ez vötte feleségül Fejérváratt Trombitás Ferencznét".

${ }^{57}$ See note 14 , above.

${ }^{58}$ Beszterce city records, IV a 25 (1590-1623), 358: "Germano Tubicinj qui [...] in occursum Ser[enissi]mi principis venit bibale [d.] 50". Kramer, "Beiträge zur Geschichte der Stadt Bistritz", 406n1.

${ }^{59}$ Beszterce city records, IV a 25 (1590-1623), 221: "Musico instrumentiste Germano Zenkenblaser [d.] 50"'. 
from that country is so far known: a certain "Christophorus Polonus, musicus", mentioned - once again - by Szamosközy. ${ }^{60}$

In 1594 Báthory confiscated the belongings of one of his nephews, István Báthory junior, but on 28 September the Prince ordered the belongings of his nephew's former organist, named Hieremias, to be restored to their owner. ${ }^{61}$ Szamosközy lists a French organist with the same surname, remarking that he died in October 1604 in Kassa (Kosiče in Slovakia). ${ }^{62}$ This Hieremias might be identical with the former musician of István Báthory, who might therefore have served at the court of the Prince from 1594 onwards.

As a result of Prince Báthory's - ultimately unfortunate - marriage to Maria Christierna Leonora (1574-1621), some musicians followed her in 1595 from Graz to Transylvania. Sadly, we lack any list for these. An Italian report written on 7 July from Kassa mentions the mandatory trumpeters and drummer in Maria Christierna's retinue. Also, the city records of Kolozsvár (4 July 1595) report the transportation of musicians of the Emperor in three carriages. Although the record employs the widely used Hungarian general term "hegedüs" (violinists), this description was commonly applied at that time to players of various kinds of "soft" instrument. ${ }^{63}$

Among Maria Christierna’s musicians, "Petrus Paulus Veronensis, musicus" is mentioned by Szamosközy as one of the Italian musicians at the Báthory court. Identifiable as Pietro Paolo Salvo, he had belonged for the previous fourteen years to the court chapel of Graz, where he "die Große Posaune blase", ${ }^{64}$ and then for four more years (1595-1599) served Maria Christierna in Transylvania.

The bassist and music copyist of the Graz court, Georg Khuglmann (Kuglmann), followed her slightly later, some time after the summer of 1596 . He mentioned in a petition of 1609 that he had "vor etlich Jaren auch dergleichen büecher in Siebenbürgen geschriben, welche von ihr Frl. Drl. Ihren geliebten Herrn brwedern Erzherzog Leopoldo bischoffen zu Passaw etc. geschenkt". These books consisted of Masses and "andern musikalischen Stuckhen". ${ }^{65}$ Kuglmann's Transylvanian manuscript, which was very likely burned in 1662 in Passau, may be similar to other surviving manuscripts today in Vienna, Graz and Ljubljana that were copied by Kuglmann and contain compositions by his contemporaries. Apart from this remark, we know of no musical sources connected with the Transylvanian court; nor are there even any traces of music inventories.

There were certainly more singers in Maria Christierna's service than Kuglmann:

${ }^{60}$ Szilágyi, Szamosközy történelmi maradványai, 76-77; Abbaffy and Kozocsa, Szamosközy István, 32.

${ }^{61}$ Peteri, Szilágy vármegye monographiája, 227; Balogh, Kolozsvári köfaragó műhelyek, 346.

${ }^{62}$ Abbaffy and Kozocsa, Szamosközy István, 32: "Ieremias Organista, Gallus, Ez Cassa[n] holt megh, 1604, mense octobri[s]".

${ }^{63}$ Kolozsvár city records, 1595, 6/XV, 132: "Brassay Geörgi vitte az Chiazar eó felsege hegedwsit Thordara 6 lovan zekere[n], [...] Pap Janos vitte vgian Azokat 3 lovan Thordaig, [...] Thorday Varga Janos vitte ugian Azokat 4 lova[n] Thord[a]ig".

${ }^{64}$ Federhofer, Musikpflege, 208.

${ }^{65}$ Federhofer, Musikpflege, 95 and 97. Kuglmann appears on the payroll of the Graz court between January and July 1596. Wallner, Musikalische Denkmäler der Steinätzkunst, 446; Federhofer, "Matthia Ferrabosco", 232; Federhofer, Musikpflege, 263 and 265. 
on 25 September 1597 and also on 30 October 1598 Kolozsvár transported her singers ("Cantores"). ${ }^{66}$

It is not known how foreigners were recruited into Báthory's court. But Prince Gabriel Bethlen's correspondence shows that he ordered his diplomats, or often other subjects (e.g., merchants or students), who were travelling abroad to find and engage appropriate musicians. It might have been similar for Báthory. One can imagine that the Italians - and not only the musicians among them - informed their countrymen in Italy, and also at other courts, that the Prince was looking for good musicians. Another factor is the already mentioned drive towards recatholization, which naturally encouraged the movement of musicians - all Catholics - from Italy to Transylvania.

Yet there is another aspect to consider: historical sources turn up more than a few people who were forced to leave their countries, former homes and places of activity to seek asylum in faraway Hungary and particularly in Transylvania, which lay far beyond the territories occupied by the Ottoman Empire. It is not very likely that the Catholic Báthory harboured Protestant refugees - who often turn up among the foreign refugees in Hungary -, but it is possible that he welcomed some people who were forced to move for other serious reasons such as debt or criminal acts. At least one hint of such a motivation has already been mentioned: the accusations against Antonio Romanini mentioned by Szamosközy.

In addition to the foreigners employed by Báthory, there were also visitors. In 1594, acting as a diplomat for Ferdinando de' Medici, the Florentine merchant Cosimo Bottegari (1554-1620) went to Gyulafehérvár and presented some silk textiles to the Prince. ${ }^{67}$ During the 1570s Bottegari had been attached to the Bavarian court as a singer and lutenist. A miscellaneous manuscript collection of lute songs and other music from around 1574 is known to be his. Bottegari also published a collection of compositions by Bavarian court musicians. ${ }^{68}$ It is questionable, however, whether around twenty years later, now a merchant-cum-diplomat, he still sang to his lute or played anything at all in Transylvania.

A short period of time was spent in Transylvania by the already mentioned musicians of the Emperor and King of Hungary, Rudolf II, who arrived in the summer of 1595, a few days in advance of Maria Christierna. But they probably left Gyulafehérvár soon after

${ }^{66}$ Kolozsvár city records, 1597, 7/XII, 81: "Makkos Janos vitte 2 Loan posta[n] Tordara Azzoniunk Cantorat"; Kolozsvár city records, 1598. 8/V, 180: "faalma Jakab vitt azzonjunknak egj kantort az klastrombol 2 lova[n] zekeren Desre".

${ }^{67}$ Budapest, Magyar Tudományos Akadémia, Kézirattár, Veress-hagyaték [Documents copied by Endre Veress], Ms. 423, 92-93, 95. - I have this information courtesy of Péter Erdősi. For Bottegari, see: Kirkendale, Court Musicians in Florence, 251-255.

${ }^{68}$ Sandberger, Beiträge zur Geschichte der bayerischen Hofkapelle, 109-110. Modena, Biblioteca Estense, Ms. mus. C. 311 (c. 1574). MacClintock, "A Court Musician’s Songbook", 177-192. Il secondo libro de madrigali a cinque voci de floridi virtuosi del serenissimo Ducca di Baviera (Venezia: Scotto, 1575), presenting works by Andrea and Giovanni Gabrieli, Orlando di Lasso, Gioseffo Guami, Ivo de Vento and Anton Gosswin, plus a madrigal by Francesco Mosto, brother of Giovanni Battista Mosto. 
the wedding. Unfortunately, there are no known sources that identify these Habsburg musicians, so we do not know who participated in the "gig" of celebratory music for it. ${ }^{69}$

Don Cesare Viadana (not the same man as Ludovico Grossi, called Viadana), a chaplain and singer serving Archduke Ferdinand of Innsbruck, reported on 5 December 1595, in a letter to the Duke of Mantua, Vincenzo Gonzaga, his impressions of Transylvania, remarking apropos of Maria Christierna "che oltre il sonare et cantare eccelentemente, che son stato fatto degno io cantare con l'Altezza Sua Ser[enissi]ma alcune delle mie Villanelle". ${ }^{70}$

Báthory's employment of musicians from abroad, and the migration of these musicians, share several features of what we know about the musical life of other Transylvanian courts, as well as music at the residences of the foremost Hungarian aristocratic families during the late sixteenth and seventeenth centuries, especially that of the Nádasdys, Batthyánys and Esterházys. Although earlier research assumed a kind of musical independence in the case of Hungary - a sort of self-sufficient musical autarchy especially marked with regard to the aristocracy - archival research of the past few decades has clearly shown that court music in Hungary indeed had a very mixed, international character. Among the musicians a great number of foreigners were active. Báthory's, and later on Gabriel Bethlen's, court are obviously not singular phenomena: they appear, rather, as two outstanding exemplifications of general trends.

Hungarian court music was clearly part of - let's simply call it - western European musical culture. On the other hand, one observes equally that Hungary, and especially Transylvania, was in a peripheral situation: its musical life and music were mixed with elements peculiar to the region. This was probably also true, albeit to a lesser extent, for Báthory's court, filled as it was with Italian musicians.

As this overview has shown, our knowledge about most of Báthory’s foreign musicians is uncertain. Only in a few cases are we in the possession of substantial details concerning their lives, careers and work: the relevant information mostly remains hidden. Still, the facts that we can glean - especially if we consider not only Báthory's reign but also court music in Hungary more generally, reveal that the foreign court musicians in Hungary belonged - so to speak - to the second tier by international standards. If such musicians were composers, we would unhesitatingly categorize them as Kleinmeister. So far we know at present, no genuinely first-class composer or instrumentalist apart from Mosto can be detected in Hungarian employment during the late sixteenth and seventeenth centuries. It is likely that even if we could gather more precise new information on some hitherto unidentified musician, the general picture would remain unchanged. Any newly discovered

${ }^{69}$ A similar "gig" involving Habsburg musicians occurred in February 1643 in celebration of the wedding of the future prince Georg Rákóczi II and Zsófia Báthory. According to contemporary reports, this was celebrated with great pomp: during the period 3-6 February 1643 numerous musicians - possibly as many as seventeen - were imported from Vienna. Kolozsvár city records, 1642, 23/X, 68, 171; 1643, 24/IV, 77-78, 222; 1643, 24/I.b, 57, 59-60, 289. See Király, “Az erdélyi fejedelmi udvar zeneélete", 1232.

${ }^{70}$ Veress, Documente, 216. For Cesare Viadana, see: Senn, Musik und Theater, 129. The mentioned Villanelle by Cesare Viadana are unknown. 
musician would belong to the same category as those already known. Nevertheless, it is probably worth emphasizing that these were nevertheless well-trained musicians.

While there is some - in certain cases much - information about Báthory's court musicians, we know regrettably little about the music they played. This is generally true for all the Transylvanian courts, as also for the residences of the Hungarian aristocracy. What repertoire was played in Báthory's period - what pieces or even simply what kind of music, in what arrangement, and how well or how badly - all this remains hidden from us. At best, we can arrive at some general conclusions and assumptions based on the diverse and scattered data.

\section{Sources and Bibliography}

\section{Archival Sources}

Cluj, Arhivele Statului Cluj, Acte fascicolate IV.

Cluj, Arhivele Statului Cluj, fond 44 Bistriţa, IVa 25 (1590-1623).

Cluj, Arhivele Statului Cluj, fond 44 Bistriţa, IIIa 8 (Magistratsprotokoll).

Cluj, Arhivele Statului Cluj, fond Primăria Cluj, city records: 1590, 4/XXI; 1592, 5/XIV; 1595, 6/XVIIa; 1596, 6/XXIX; 1597, 7/XII; 1598, 8/V; 1642, 23/X; 1643, 24/I.b; 1643, 24/IV.

Budapest, Magyar Tudományos Akadémia, Kézirattár, Veress-hagyaték, Ms. 423.

Mantova, Archivio di Stato, Archivio Gonzaga: busta 395; busta 410B, reg. 43; busta 468, fasc. II 2; busta 525.

Modena, Biblioteca Estense, Ms. mus. C. 311 (ca. 1574).

Rome, Archivio Doria-Pamphilij Fondo Aldobrandini, busta 5.

Rome, Bibliotheca Vaticana, Fondo Ferraiuoli, no. 43.

Rome, Biblioteca Apostolica Vaticana, Urb.lat. 817. pt. 2.

Innsbruck, Tiroler Landesarchiv, Regierungskopialbuch, 82 (1595-1599) and 84 (1598/1599).

\section{LiTERATURE}

Balogh, Jolán. Kolozsvári köfaragó mühelyek [The lapidary workshops of Kolozsvár]. Budapest: Magyar Tudományos Akadémia Müvészettörténeti csoport, 1985.

Bárdos, Kornél. "Fejedelmi és fóúri zeneélet" [The musical life of the princes and the high nobility]. In Magyarország zenetörténete (1541-1686), edited by Kornél Bárdos, vol. 2, 102-109. Budapest: Akadémiai kiadó, 1990.

Barlay, Ö. Szabolcs, and András Pernye. “Girolamo Diruta: Il Transilvano”. Magyar Zene 20, no. 1 (1979): 39-59.

Bascapè, Giacomo. Le Relazioni fra L'Italia e la Transilvania nel secolo XVI. Rome: Anonima Romana Editoriale, 1931.

Bethlen, Wolfgang (Farkas). Historia de rebus Transsilvanicis. Vol. 3. Cibinii (Hermannstadt): Hochmeister, 1783.

\section{9.}


Büsching, Johann Gustav, ed. Jahrbücher der Stadt Breslau von Nikolaus Pol. Vol. 4. Breslau: Graß und Barth, 1823.

Caffi, Francesco. Storia della musica sacra nella già cappella ducale di San Marco in Venezia. Vol. 1. Venice: Antonelli, 1854.

Canal, Pietro. Della musica in Mantova. Venice: Antonelli, 1881.

Constantinescu, Radu. "Muzica în Transilvania 1438-1648”. In Studii de muzicologie, XVII, 143-178. Bucharest: Ed. muzicală a Uniunii compozitorilor din Republ. Soc. România, 1983.

Abbaffy, Erzsébet E., and Sándor Kozocsa, eds. Magyar nyelvü kortársi feljegyzések Erdély múltjából, Szamosközy István történetíró kézirata. XVII. század eleje [Contemporary Hungarian notices on the history of Transylvania, the manuscripts of I. Szamosközy. Beginning of the seventeenth century]. Budapest: Akadémiai kiadó, 1991.

Federhofer, Hellmut. "Matthia Ferrabosco". Musica Disciplina 7 (1953): 205-233. . Musikpflege und Musiker am Grazer Habsburgerhof der Erzherzöge Karl und Ferdinand von Innerösterreich (1564-1619). Mainz: B. Schott's Söhne, 1967.

Fleischman von Puntzelwitz, Peter. Kurtze vnd aigentliche Beschreibung des zu Regenspurg in diesem 94. Jar gehaltenen Reichstag. Regensburg: A. Burger, 1594.

Fökövi, Ludwig. "Die Zigeunermusik in Ungarn”. Monatshefte für Musikgeschichte 30, no. 12 (1898): 145-148.

Gárdonyi, Albert. "A Báthoryak és a Zenemüvészet” [The Báthorys and music]. Muzsika 1, no. 6-7 (1929): 33-36.

Gaspari, Gaetano, ed. Catalogo della Biblioteca del Liceo Musicale di Bologna, vol. 2. Bologna: Libreria Romagnoli Dall'Acqua, 1892.

Kovács, András ed. Gyulafehérvár város jegyzőkönyvei [The city protocols of Gyulafehérvár]. Erdélyi történelmi adatok, vol. VI, no. 2. Kolozsvár: Erdélyi Múzeum-Egyesület, 1998. Haraszti, Emil (Emile). "Sigismond Báthory, Prince de Transylvanie et la musique italienne”. Revue de musicologie 12 (1931): 190-213. https://doi.org/10.2307/925616. . “Il Transilvano' di Girolamo Diruta”. Corvina 6, no. 3 (1943): 117-127.

Horstmann, Angelika. Katalog der Musikdrucke aus der Zeit der Kasseler Hofkapelle, 1550-1650. Wiesbaden: Harrassowitz, 2005.

Király, Peter. "Giovanbattista Mosto - egy 16. századi ‘száguldó muzsikus”" [Giovanbattista Mosto, a ‘raging musician' of the sixteenth century]. In Magyarország és Európa. Zenetörténeti írások by Peter Király. Budapest: Balassi Kiadó, 2003.

- "An Internationally Renowned Virtuoso from Hungary: Valentin Bakfark". In Music in Hungary: An Illustrated History, edited by János Kárpáti, 65-74. Budapest: Rózsavölgyi, 2011.

- "Az erdélyi fejedelmi udvar zeneélete a két Rákóczi György korában" [The Transylvanian court music at the time of the two Georg Rákóczis]. Századok 146, no. 5 (2012): 1227-1249.

. "Foreign musicians and their influence in sixteenth- and seventeenth-century Hungary". In A Divided Hungary in Europe: Exchanges, Networks and Representations,1541-1699, edited by Gábor Almási, 253-270. Newcastle upon Tyne: Cambridge Scholars Publishing, 2014.

____ . "Giovanni Battista Mosto figyelembe nem vett Báthory Zsigmondnak ajánlott 
zenei kiadványa 1590-böl” [A neglected music edition from 1590 by Giovanni Battista Mosto, dedicated to Sigismund Báthory]. Magyar könyvszemle 120, no. 4 (2004): 384-387.

- "Giovanni Battista Mosto". In Die Musik in Geschichte und Gegenwart, 2nd ed., edited by Ludwig Finscher, Personenteil, 12:540-541. Kassel: Bärenreiter; Stuttgart: Metzler, 2004.

- "Valentin Bakfark - Anfangsjahre eines siebenbürgischen Musikers von europäischem Rang”. In Konfessionsbildung und Konfessionskultur in Siebenbürgen in der frühen Neuzeit, edited by Volker Leppin and Ulrich A. Wien, 201-210. Stuttgart: Franz Steiner Verlag, 2005.

Kirkendale, Warren. The Court Musicians in Florence during the Principate of the Medici. Florence: Olschki, 1993.

Kramer, Friedrich. "Beiträge zur Geschichte der Stadt Bistritz in den Jahren 1600-1603". Archiv des Vereins für Siebenbürgische Landeskunde 12 (1875) 395-445.

Lindell, Robert. “Das Musikleben am Hof Rudolfs II.”. In Prag um 1600: Kunst und Kultur am Hofe Rudolfs II., 75-83. Freren: Luca Verlag, 1988.

Lukács, Ladislaus. Monumenta Antiquae Hungariae, 1587-1592. Vol. 3. Rome: Institutum historicum S. J., 1981.

MacClintock, Carol. “A Court Musician's Songbook: Modena Ms. C 311”. Journal of the American Musicological Society 9 (1956): 177-192. https://doi.org/10.2307/829881.

Németh S., Katalin. "Erdélyi fejedelmi udvar Marchthaler útleírásában” [The Transylvanian court in the description of Marchthaler]. In Idövel paloták [...] Magyar udvari kultúra a 16-17. században [Hungarian court culture in the sixteenth and seventeenth century], edited by Ildikó Horn and Nora G. Etényi, 331-339. Budapest: Balassi kiadó, 2005.

Petri, Mór, ed. Szilágy vármegye monographiája [Monography on the county Szilágy]. Vol. 2. N.p., 1901.

Sandberger, Adolf. Beiträge zur Geschichte der bayerischen Hofkapelle unter Orlando di Lasso. Vol. 3. Leipzig: Breitkopf \& Härtel, 1895.

Senn, Walter. Musik und Theater am Hof zu Innsbruck. Innsbruck: Österreichische Verlagsanstalt, 1954.

Szilágyi, Sándor ed. Szamosközy István történelmi maradványai [Historical remainders of I. Szamosközy]. Vol. 4. Budapest: Magyar Tudományos Akadémia, 1880.

Veress, Endre. Erdélyországi pápai követek jelentései VIII. Kelemen idejéböl [Reports of the papal legate from the time of Pope Clement VIII]. Monumenta Vaticana Historiam Regni Hungariae illustrantia, ser. 2, vol. 3. Budapest: Franklin Társulat, 1909.

-, ed. Documente privitoare la istoria Ardealului, Moldovei şi Ţârii-Româneşti [Documents concerning the history of Transylvania], Vol. 4. Bucharest: Imperia Naţionăla, 1932.

Waldner, Franz. "Verzeichnis der Organisten Sänger und Instrumentisten am Hofe zu Innsbruck unter Erzherzog Ferdinand 1567 bis 1596". Monatshefte für Musikgeschichte 36 (1904): 143-155.

Wallner, Bertha Antonia. Musikalische Denkmäler der Steinätzkunst des 16. und 17. Jhs. nebst Beiträgen zur Musikpflege dieser Zeit. Munich: Lentner, 1912. 
Windisch, Éva V., ed. Kemény János és Bethlen Miklós müvei [Works of J. Kemény and M. Bethlen]. Budapest: Szépirodalmi könyvkiadó, 1980.

Zászkaliczky, Tamás, András Pernye and Szabolcs Barlay Ö., eds. Il Transilvano, Keyboard Music from the 16th and 17th Century. Musica per la Tastiera, 3. Budapest: Editio Musica, 1981. 


\title{
TUJI GLASBENIKI NA TRANSILVANSKEM DVORU SIGISMUNDA BÁTHORYJA
}

\author{
Povzetek
}

Zgodovinski viri iz 16. in 17. stoletja pričajo o tem, da so transilvanski vladarji med iztekajočim se petim desetletjem 16. stoletja in sredino četrtega desetletja naslednjega stoletja bolj ali manj stalno zaposlovali tudi tuje glasbenike. To še posebej velja za Sigismunda Báthoryja (1572-1613, s presledki je vladal od 1581 do 1601), ki je imel v svoji službi vrsto glasbenikov iz tujine. Gerolamo (običajno Girolamo) Diruta je Báthoryja označil kot »srčnega ljubitelja glasbe in koncertov«. Sigismundu Báthoryju so med 1590 in 1599 skladatelji Giovanni Battista Mosto, Gerolamo Diruta, Philippe de Monte in Giovanni Bassano posvetili pet v Benetkah tiskanih glasbenih zbirk.

V službi transilvanskega kneza Báthoryja so bili številni tuji glasbeniki, največ je bilo Italijanov, a tudi nekaj glasbenikov nemškega izvora in presenetljivo samo en Poljak. Trenutno je znanih malo več kot ducat imen italijanskih glasbenikov, ki so bili aktivni v času njegove vladavine (1581/1588-1599) in ki so prišli ali izhajali iz naslednjih italijanskih krajev: Ancona, Bologna, Brescia, Genova, Rim, Videm in predvsem Benetke. Njihovo predhodno delo v italijanskih središčih, kot sta Padova ali Benetke, ali pa na dvorih v Firencah, v Mantovi ali v Gradcu in Salzburgu, je večinoma sorazmerno dobro znano. Nekateri viri nakazujejo celo, da so bili italijanski glasbeniki v Transilvaniji prisotni že v osemdesetih letih 16. stoletja.

Znani skladatelj Giovanni Battista Mosto iz Vidma je od okoli 1590 do 1595/96 (a po 1593 s prekinitvami) služil kot Báthoryjev magister capellae. Umrl je v Transilvaniji spomladi ali poleti leta 1596 in je pokopan v katedrali mesta Gyulafehérvár. Mosto je transilvanskemu knezu posvetil dva od svojih tiskov: Motecta quinque vocum leta 1590 in Il primo libro de madrigali leta 1595. Tam objavljene skladbe naj bi ustvaril predvsem v Transilvaniji.

Antonio Romanini iz Benetk, učenec Andree Gabrielija, je nastopil službo pri Báthoryju v Transilvaniji najpozneje poleti leta 1592 in je tam ostal vsaj do 1598/99. Romanini je odigral pomembno vlogo kot posrednik med beneškimi glasbeniki in Báthoryjevim dvorom v Gyulafehérvárju.

Posledica poroke kneza Báthoryja s habsburško nadvojvodinjo Marijo Christierno (Christino) leta 1595 je bil tudi prihod več glasbenikov iz Gradca. Med njimi je bil tudi basist in graški dvorni kopist Georg Khuglmann (Kuglman).

Báthoryjevo zaposlovanje tujih glasbenikov je podobno tistemu, ki ga poznamo iz glasbenega življenja poznejših transilvanskih dvorov v 17. stoletju, kot tudi mecenstvu najvplivnejših madžarskih plemiških družin v 16. in 17. stoletju, še predvsem Nádasdyjev, Batthyányjev in Etserházyjev. 